\title{
STUDIES OF ANTITHYROID ANTIBODIES IN DOWN'S SYNDROME
}

B. J. 8CHMIDT*
4. L. O. 8CHALCH **
H. M. 8OU8A **
8. PIVA *

C. ORTEGA ***

D. B. TORRES ***

8. RRYNBKI****

Based on the fact that autoimmunity may lead to cromosome aberrations and that the antithyroid antibodies are found in a number of patients with Down's syndrome as well in part of their respective mothers, some publications suggested that the antithyroid antibodies of the mother could lead to Down's syndrome in the child.

Burgio et a1.3,4 found out that 7 out of 12 mothers of mongoloids had antithyroglobulin antibodies. The papers of Fialkow et al. 6,7,8 showed in the same populational area a greater increase of antithyroid antibodies in about 28\% mothers of mongoloids (42 out of 148). These comparative studies ${ }^{9}$ showed also that the incidence of antithyroid antibodies was greater in young mothers and with children affected by Down's syndrome - the ages varying from 20 to 32 years.

Harris and Kousoulieris 11 refer to high antithyroid antibodies in a 4 years old mongoloid and Aarskog 1 describes 3 mongoloid children with antithyroglobulin antibodies - these antibodies were also found in 2 mothers of these patients.

In the present work we studied the incidence of antithryroid antibodies in patients with Down's syndrome and in their respective mothers to verify the incidence of these antibodies.

\section{METHODS}

Forty non-institutionalized patients clinically and cytogenetically characterized as suffering from Down's sndrome were selected. The age of the patients ranged from 5 months, to 21 years old, 24 of them being males and 16 females: the mothers of these patients, whose ages varied from 22 to 66 years old, were also studied. The methods

Trabalho apresentado na XV Renibo Anual da Sociedade Latino-Americana de Investigaçăo Pediátrica, Cochabamba, Bolíla (5-7 dezembro, 1977), realizado no Centro de Habilitaçăo de săo Paulo em colaboraça com o Dopartamento de Pediatria da Hacola Paulista de Medicina (HPM), Servico do Professor A. A. Carvalho: * Professor Adjunto e Docente Livre do Departamento de Pediatria da FPM; ** Médicos; *** Bioquímicos do Centro de Habilitaçăo de Săo Paulo; *** Diretor Técnico do Centro de Habilitagáo de sao Paulo. 
used for the determination of serum antithyroglobulin antibodies were hemagglutination and indirect immunofluorescence; for the antimicrosomal antibodies, the indirect methods of immunofluorescence and hemagglutination with antigens prepared from human thyroid of patients who had the Graves-Basedow's Illness, absorbing it in sheep erythroaytes previously fixed using a modification of the technics described by Fujita \& Yamadas and by Doniach 10.

\begin{tabular}{|c|c|c|c|c|}
\hline Case & Registration & Age & Sex & $\begin{array}{c}\text { Mother's age } \\
\text { (years) }\end{array}$ \\
\hline 1 & 3365 & $7 y$ & $\mathbf{m}$ & $\mathbf{3 1}$ \\
\hline 2 & 3381 & $11 y$ & $\boldsymbol{t}$ & 35 \\
\hline $\mathbf{3}$ & 3414 & $2 \mathbf{y}$ & $\mathbf{m}$ & 40 \\
\hline 4 & 3410 & $8 \mathbf{y}$ & $\mathbf{f}$ & 29 \\
\hline 5 & 3408 & $4 y$ & $\mathbf{m}$ & 41 \\
\hline 6 & 3437 & $1 \mathbf{y}$ & $\mathbf{m}$ & 28 \\
\hline 7 & 3452 & $7 y$ & $\mathbf{m}$ & 48 \\
\hline 8 & 3429 & $3 \mathbf{3 y}$ & $\mathbf{m}$ & 45 \\
\hline 9 & 3469 & $1 y 8 m o$ & $\mathbf{m}$ & 37 \\
\hline 10 & 3514 & $14 y$ & $\mathbf{m}$ & 55 \\
\hline 11 & $\mathbf{3 4 7 0}$ & $2 y$ & $\mathbf{f}$ & $\mathbf{3 1}$ \\
\hline 12 & 3444 & $\mathbf{3 y}$ & $\mathbf{m}$ & 31 \\
\hline 13 & 3493 & $1 \mathbf{y}$ & $\mathbf{f}$ & 43 \\
\hline 14 & 3464 & $7 y$ & $\mathbf{f}$ & 38 \\
\hline 15 & 3494 & $5 y 2 \mathrm{mo}$ & $\mathbf{m}$ & 34 \\
\hline 16 & 3509 & $5 \mathrm{mo}$ & $\mathbf{m}$ & 22 \\
\hline 17 & 3521 & $5 \mathbf{y}$ & $\mathbf{m}$ & 42 \\
\hline 18 & 3519 & $14 y$ & $\mathbf{t}$ & 52 \\
\hline 19 & 3564 & 5mo & $\mathbf{f}$ & 31 \\
\hline 20 & 3236 & $\mathbf{1 y}$ & $\mathbf{m}$ & 28 \\
\hline 21 & 3518 & $13 y$ & $\mathbf{m}$ & 44 \\
\hline 22 & 3570 & $4 y$ & 1 & 33 \\
\hline 23 & $\mathbf{3 5 8 4}$ & $6 y$ & $\mathbf{m}$ & 46 \\
\hline 24 & 3596 & $5 y$ & $\mathbf{m}$ & 27 \\
\hline 25 & 3598 & $\mathbf{3 y}$ & $\mathbf{I}$ & 43 \\
\hline 26 & 3605 & $7 y$ & $\mathbf{I}$ & 46 \\
\hline 27 & 3611 & $6 y$ & $\mathbf{f}$ & 42 \\
\hline 28 & 3613 & $1 \mathrm{y} 6 \mathrm{mo}$ & $\mathbf{m}$ & 22 \\
\hline 29 & 3635 & $1 y$ & $\mathbf{m}$ & 29 \\
\hline 30 & 3600 & $13 y$ & $\mathbf{m}$ & 55 \\
\hline 31 & 3648 & $6 y$ & $\mathbf{e}$ & 46 \\
\hline 38 & 3661 & $1 \mathbf{y}$ & $\mathbf{m}$ & 30 \\
\hline 33 & 3708 & $8 \mathrm{mo}$ & $\mathbf{m}$ & 28 \\
\hline 34 & 3718 & $7 y$ & $\mathbf{m}$ & 50 \\
\hline 35 & 3748 & $4 \mathrm{mo}$ & $\mathbf{f}$ & 41 \\
\hline 36 & 3697 & $\mathbf{7 y}$ & $\mathbf{f}$ & 49 \\
\hline 37 & 3807 & $17 y$ & $\mathbf{m}$ & 55 \\
\hline 38 & 3693 & $2 y$ & $\mathbf{m}$ & 29 \\
\hline 39 & 3712 & $9 y$ & $\mathbf{I}$ & 45 \\
\hline 40 & 3717 & $21 y$ & 1 & 66 \\
\hline
\end{tabular}

Table 1 - Listing of ages and sex of the studied pationts, with the ages of their respective mothers: $\dot{m}=$ male; $f=$ female; $Y-$ years; mo $=$ months. Number or regiotration at the Centro de Habilitagdo de $8 d_{0}$ Paulo. 


\section{RESULTS}

Table 1 lists the studied patients, their ages and sex and the ages of their respective mothers. In none of the analyzed sere of the mongoloids as well as of their mothers, antithyroid antibodies (antithyroglobulin and antimicrosomal) were detected.

\section{COMMENTS}

Antithyroids antibodies have been more frequently found in sera of mothers who had children with hipotiroidism without goiter compared to mothers who had normal children ${ }^{2}$. These antibodies may pass through the placenta and are present in some cases of children with hipothyroidism without goiter.

The higher incidence of these antithyroid antibodies in mothers of mongoloids suggests that there is correlation between these antithyroid antibodies and Down's syndrome. In this study we could not detect the antithyroid antibodies (antithyroglobulin and antimicrosomal) in anyone of the 40 patients with Down's syndrome nor in anyone of their respective mothers. Saxena \& Pryles 12 detected these antithyroid antibodies only in 2 of 30 mothers of mongoloids. Sutherland et al. 13 showed that the majority of mothers of children with hipothyroidism without goiter had no detectable thyroid alternations or antithyroid antibodies. On the other hand, many mothers with thyroid antibodies have normal children. In reality, the agent which would cause the thyroid destruction "in vivo" or of the fetal thyroid has not yet been found and the real meaning of the presence of these antibodies is not perfectly clear.

\section{SUMMARY}

The presence of antithyroid antibodies (antithyroglobulin and antimicrosomal) in the serum of patients with Down's syndrome and their respective mothers were studied based on data from the literature, showing a possible correlation between the presence of these antibodies in the serum of mothers and the birth of mongoloid children. Antithyroid antibodies were studied in 40 patients with Down's syndrome, with ages ranging from 5 months to 21 years old, 24 males and 16 females and in the respective mothers whose ages varied from 22 to 66 years. In none of the analyzed sera of the mongoloids as well of their mothers, the authors were able to detect the antithyroid antibodies studied.

\section{RESUMO}

\section{Anticorpos antitireóide na síndrome de Down.}

Foi estudado no soro de pacientes com síndrome de Down e suas respectivas mães, a presença de anticorpos antitireóide (antitireoglobulina e antimicrossomal), tendo em vista dados de literatura mostrando uma eventual correlação entre a presença destes anticorpos, no soro de mães com filhos. mongolóides. Os anti- 
corpos antitireoideanos foram dosados em 40 pacientes com síndrome de Down, cuja idades variavam 5 meses a 21 anos, sendo 24 masculinos e 16 femininos e, nas respectivas mães, cujas idades variaram de 22 a 66 anos de idade. Em nenhum dos soros analisados, quer dos mongolóides bem como de suas respectivas mães, conseguiu-se detectar os anticorpos antitireoideanos estudados.

\section{REFERENCES}

1. AARSKOG, D. - Autoimmune thyroid disease in children with mongolism. Arch. Dis. Childh. 44:454, 1969.

2. BLIZzARD, R. M.; ChandLer, R. N.; PETIT, M. D. \& WeSt C. D. - Maternal autoimmunization as a probable cause of athyrotic cretinism. New Engl. J. Med. $263: 327,1960$.

3. BURGIO, G. R.; SEVERI, F.; ROSSONI, R. \& VACCARO, R. - Mongolism and thyroid autoimmunity. Lancet. I:166, 1965.

4. BURGIO, G. R.; SEVERI, F.; ROSSONI, R. \& VACCARO, R. - Autoantibodies in Down's syndrome. Lancet. I:497, 1966.

5. DONIACH, D. - Hormonal and genetic aspects of thyroid autoimmunity. In Clinics in Endocrinology and Metabolism - W. J. IR'vINE, editor. Volume 4. W. B. Saunders Co., London, 1975, p. 267.

6. FIALKOW, P. J.; HECHT, F.; BRYANT, J. \& MOTULSKY, A. G. - Familiar predisposition to chromosomal aberrations. Clin. Res. 13:124, 1965.

7. FIALKOW, P. J.; HECHT, F.; UCHIDA, I. A. \& MOTULSKY, A. G. - Increased frequency of thyroid autoantiboties in mothers of patients with Down's syndrome. Lancet II:868, 1965.

8. FIALKOW, P. J. - Autoimmunity and chromosomal aberration. Amer. J. Human. Genet. 18:98, 1966.

9. FIALKow, P. J. - Thyroid antibodies Down's syndrome and maternal age. Naturc $214: 1253,1967$.

10. FUJITA, K. \& YAMADA, N. - Haemagglutination test utilizing the microsomal antigen from thryroid epithelial cells. Clin. Pathol. (Japan) 18:213, 1970.

11. HARRIS, F. \& KOUTSOULIERIS, E. - Hypothynoidism due to autoimmune thyroiditis in a young child wilth Dow's syndrome Arch. Dis. Childh. 42:449, 1967.

12. SAXenA, K. M. \& PRYLes, C. V. - Thyroid function in mongolism. J. Pediat. $67: 363,1965$.

13.SUTHERLAND, J. M.; ESTELBORN, V. M.; BURKET, R. L.; SKILLMAN, T. B., \& BENSON, J. T. - Familial non goitrous cretinism apparently due to maternal antithyroid antibody: Report of a family. New Engl. J. Med. 263:336, 1960.

Departamento de Pediatria - Escola Paulista de Medicina - R. Botucatí 720, a4203 sáo Paulo, SP - Brasil. 